\title{
EFFECT OF ADDED TOCOPHEROLS ON THE STABILITY OF PALM OLEIN AND BISCUITS CONTAINING PALM OLEIN STORED AT TROPICAL CONDITIONS
}

\author{
Shaltout, Omayma, E. ${ }^{1}$, El-Sini, Madeha, N. $^{2}$ \& El-Khateib, Mona, H. $^{3}$ \\ ${ }^{1}$ Food Science Dept., Fac. of Agric. (Saba Basha), Alex. Univ., Alexandria, Egypt. \\ ${ }^{2}$ Biochemistry Dept., Fac. of Sci., King Abdulaziz Univ., Jeddah, KSA. \\ ${ }^{3}$ Food \& Nutrition Dept., Home Economics, King Abdulaziz Univ., Jeddah, KSA.
}

\begin{abstract}
The oxidative stability of palm olein oil, with an added synthetic antioxidant, namely; Tenox 25 (T25) and two concentrates of tocopherol mixtures, namely, Covi Ox-T50 (Covi 50) and Covi Ox-T70 (Covi 70) was evaluated for 4 months storage under tropical conditions. The oxidative stability of palm olein oil stored under the aforementioned conditions was monitored by determining the conjugated dienes (CD), acid value (AV), free fatty acid (FFA), peroxide value (PV), p-anisidine value (PA), iodine value (IV) and the total oxidation value (TOTOX). The antioxidant index (AI) was also calculated. The quality of biscuits containing palm olein oil was also evaluated under the aforementioned storage conditions.

Data were analysed by the general linear analysis. Results of the oxidation measurements showed that the activity of the individual antioxidants used in the present study varied with the same type of oil, but in most of the tests, the tocopherols were as equally effective as the strong synthetic T25 and/or more superior than it in many aspects. The AI for the different antioxidants had values higher than unity and were similarly effective as T25 indicating their antioxidative powers in inhibiting the onset of rancidity in the stored oil.

Results of the quality tests of the stored biscuits indicated that the low concentrate tocopherol Covi 50 significantly $(\mathrm{P}<0.05)$ prevented moisture loss and rancidity development as measured by the thiobarbituric acid number (TBA) as compared to the other antioxidants. Both added tocopherols and T25 were equally effective in preventing the $\mathrm{pH}$ rise of the stored biscuits as compared to the control. The sensory evaluation showed that higher scores were given by the panelists for all antioxidant treated samples without differentiation.
\end{abstract}

Keywords : quality, palm olein oil, lipid oxidation, antioxidants, tenox 25, mixed tocopherols.

\section{INTRODUCTION}

The shelf-life of foods is becoming more and more important due to the increasing amount of manufactured foods needed for feeding the growing world population and to the demographic shift from rural to urban areas (Loliger \& Wille, 1993, Pszola, 2001).

Most foods contain a certain percentage of lipids. Lipids of plant origin are normally more unsaturated than those of animal origin, their molecules contain functional groups that react with oxygen under certain conditions (Buck \& Edwards, 1997).

The shelf-life of foods is often limited as their stability is restricted due to reactions such as oxidative degradation of lipids. Oxidation of lipids not only produces rancid odours and flavours, but can decrease the nutritional quality and safety by the formation of secondary products in foods after cooking and processing (Loliger \& Wille 1993, Frankel 1996, Shahidi, 1996). Heat oxidation is typical of most chemical reactions, a $10^{\circ} \mathrm{C}$ increase in temperature essentially doubles the reaction rate (Buck \& Edwards, 1997). Another important aspect of lipid auto-oxidation and its retardation during storage of prepared food is the potential risk to health due to lipid auto-oxidation degradation products (Loliger, 1991, Shahidi, 1996, Romero et al., 1998).

The use of synthetic phenolic antioxidants has proved to be an effective and economical method of inhibiting oxidative 
changes in food ingredients (Loliger \& Wille, 1993). A number of chemicals have been specifically designed to function as radical scavengers and have been in use in the food industry for many years. These include butylated hydroxyanisole (BHA), butylated hydroxytoluene (BHT) and tertiary butylated hydroxyquinone (TBHQ) and the gallets (Loilger, 1991, Topliss et al., 2002). However, consumer preferences and government regulations some times prohibit the use of synthetic antioixidants. Some studies have suggested the involvement of these antioxidants in cancer tissue initiation and in cancer tissue propagation (Frankel, 1996, Shahidi, 1996). Thus, natural antioxidants can assist the food manufacturer in such cases. Evidence is accumulating that natural antioxidants in foods may have clear benefits because they have anticarcinogenic effects and inhibit biologically harmful oxidation reactions in the body (Frankel 1996, Shahidi 1996, Tomasch \& Elmadfa 2001).

Tocopherols are very common antioxidants in nature. They are wide spread in vegetable oils, from which they can be obtained by special enrichment procedure. They are responsible for the inherent stability of many vegetable oils. Due to their high molecular weight, tocopherols resist high temperature processing. They are carried through into the final product and impart protection. Therefore, tocopherols can be applied to processed products such as baked goods, fried food and other heat-treated foods (Poller 1992, Loliger \& Wille 1993, Berry, 2003).

Naturally occurring tocopherols are composed primarily of the $\alpha$-, $\beta$-, $\gamma$-, and $\delta$-homologues. $\alpha$-tocopherols is physiologically active and is known as vitamin E, it has considerable antioxidant properties but less than $\gamma$ and $\delta$-tocopherols (Buck \& Edwards, 1997, Berry, 2003).

Studies conducted by Anon (1991), Gordon \& Kourimska (1995), Eastman (1995) and Allam \& Mohamed (2002) confirmed the effectiveness of synthetic antioxidants in inhibiting the onset of oxidation versus some natural antioxidants in diffirent oils. On the other hand, Wu (1994) studied the effect of natural antioxidants on the oxidative stability of oils containing high concentration of polyunsaturated fatty acids. Results showed that the addition of $0.1 \%$ Covi 70 (natural tocopherol),
0.02\% centrolex (soybean lecithin) to the tested oil increased oil induction time from 0.9 to $25.93 \mathrm{~min}$. as determined by the rancimat method. The effectiviness of individual tocopherols and their mixtures in inhibiting the formation and decomposition of hydroperoxides were studied by Haung et al. (1995) and Barrera et al., (2002).

Information from the literature is insufficient to establish the relationship between the different concentrations of tocopherol mixtures and storage conditions as related to lipid oxidation in some oils and food products made from them.

The aim of the present study was to evaluate the effect of adding two concentrates of natural tocopherols mixtures versus a synthetic one on the stability of palm olein oil as well as the quality of biscuits containing palm olein oil stored under tropical conditions (temperature range $37-45$ and $95 \% \mathrm{RH}$ ) typical to Jeddah City, KSA.

\section{MATERIALS AND METHODS}

\section{Materials}

Palm olein: A batch of $10 \mathrm{~kg}$ of refined palm olein oil was provided from Saffola Oil Company (Saudi Arabia). No antioxidants were added or indicated in the label.

Antioxidants: Two concentrates of natural tocopherols namely Covi-Ox T50 (Covi 50) and Covi-Ox T70 (Covi 70) were purchased from Henkel Corporation, IL, USA. Both are clear brownish red viscous oil containing mixed tocopherol concentrate. The tocopherols contained d- $\alpha 14 \%$, d- $\beta 1 \%$, d- $\gamma$ $62 \%$ and $\mathrm{d}-\delta 23 \%$. Each gram of Covi 50 contains 500mg of total tocopherols, where each gram of Covi 70 contains $700 \mathrm{mg}$ of total tocopherols. A synthetic type of antioxidant namely Tenox 25 (T25) was purchased from Eastman Chemical Company, TN, USA. It is a viscous golden brown oil containing $10 \%$ butylated hydroxytoluene (BHT) and 10\% tertiarybutylated hydroquinone (TBHQ) and $3 \%$ citric acid.

Biscuit ingredients: Flour, sugar, salt, eggs, baking powder and vanilla were purchased from a supermarket in Jeddah City, KSA.

\section{Methods}

Antioxidants application: All antioxidants were added at $0.02 \%$ based on the fat weight according to FDA regulations and 
Doughrety (1988). The antioxidants were applied to the oil according to the direct method of Eastman (1996) by heating the oil to $60^{\circ} \mathrm{C}$ $\left(140^{\circ} \mathrm{F}\right)$ and agitating sufficiently to dissolve the antioxidant. The gentle agitation was continued for an additional 20 min. to ensure uniform distribution.

Biscuits preparation: The following ingredients were used in the formulation of a baking powder biscuit type as $\mathrm{g} / 100 \mathrm{~g}$ of the total ingredients: wheat flour $42.8 \%$, sugar $19.9 \%$, palm olein $17.1 \%$, eggs $17.9 \%$, salt $0.3 \%$, baking powder $1.5 \%$ and vanilla $0.1 \%$. Biscuits were prepared as followed by Conforti et al. (1997). The resulting biscuits with different added antioxidants and control were put in plastic plates, wrapped with polyethylene cover and stored for 4 months at room temperature which ranged between 37 and $45^{\circ} \mathrm{C}$ typical to Jeddah City in KSA. Samples were evaluated for chemical and sensorical tests at constant intervals of one month.

Analytical methods: Palm olein oil with different added antioxidant concentrations and control were kept in capped glass jars and stored at tropical room temperature $\left(37-45^{\circ} \mathrm{C}\right)$ for 4 months examined for the development of oxidation rancidity at one month interval. Oxidative rancidity in the oil was evaluated by measuring the conjugated dienes (CD) at 234nm absorbance (IUPAC, 1978). The hydrolytic rancidity was evaluated by determining both the acid value (AV) and the free fatty acid content (FFA) method No. 28.029 expressed as g palmitic acid $\mathrm{Kg}^{-1}$ (IUPAC, 1979). The peroxide value (PV) was determined according to AOCS (1990) and expressed in units of $\mathrm{mEq} / \mathrm{O}_{2} \mathrm{Kg}$ sample.

The iodine value (IV) was determined according to the Wijs' method described in Egan et al. (1981). The para-anisidine value (PA) was determined by AOCS (1990). The total oxidation value (TOTOX) which is used to determine the effectiveness of stored oils was calculated according to IUPAC (1979) as following: TOTOX value $=$ anisidine value +2 (peroxide value). The antioxidant index (AI) was calculated by dividing the $\mathrm{PV}$ of the control by that of the treatment for the same storage time. Values above unity indicate antioxidant activity while values below unity indicate prooxidant activity (Bishov \& Henick, 1972).

Quality tests of biscuits: The moisture content of the biscuits was carried out using an electric air oven at $105 \pm 0.5^{\circ} \mathrm{C}$ for $2-3 \mathrm{hrs}$ until constant weight (AOAC, 1984). A 10 gram sample of biscuits was ground thoroughly, mixed in $90 \mathrm{ml}$ distilled water for the $\mathrm{pH}$ measurement using an ATC $\mathrm{pH}$ meter G353, UK. The thiobarbituric acid number (TBA) was measured as described by Tarladgis et al. (1960) and expressed as mg malonaldehyde $/ \mathrm{kg}$ sample.

Sensory evaluation: The biscuits were evaluated for sensory attributes every one month interval for 4 months by means of ten panelists from the Department of Food and Nutrition King Abdulaziz University, Jaddah, KSA, where an evaluation sheet was distributed for the ranking test. The attributes tested were colour, odour, taste, texture and overall acceptance. Scores were distributed on a five point scale ranging between 1 and 5, where 5 stands for maximum acceptance and 1 for maximum rejection due to negative distinct changes in one or more of the tested attributes. Tap water and salt crackers were introduced between each treatment (Moskwitz 1985).

Statistical analysis: Data were analysed by ANOVA using the general linear model (GLM) procedure (SAS, 1985) using treatments (antioxidants) and time (4 months storage) as fixed effects. Differences between means were further differentiated by Duncan's Multiple Range Test. Significance was defined at $\mathrm{P}<0.05$.

\section{RESULTS AND DISCUSSION}

Oxidation rancidity of palm olein oil stored at tropical conditions: The antioxidant application of both tocopherols and $\mathrm{T} 25$ (Fig. 1) significantly $(\mathrm{P}<0.05)$ lowered the conjugated dienes (CD) values of the stored palm olein oil under the experimental conditions as compared to control. Both Covi 50 and Covi 70 were more pronounced in this respect as compared to the synthetic $\mathrm{T} 25$ and control. The formed CD exhibited intense absorption at $234 \mathrm{~nm}$, due to a shift in the double-bond position of lipids containing methylene interrupted dienes during oxidation. The absorption increase is proportional to the uptake of oxygen and formation of perioxdes in early stages of oxidation (Longani \& Davis, 1980).

Results concerning both the acid value (AV) and free fatty acid (FFA) values of the stored palm olein oil indicated that only the low 

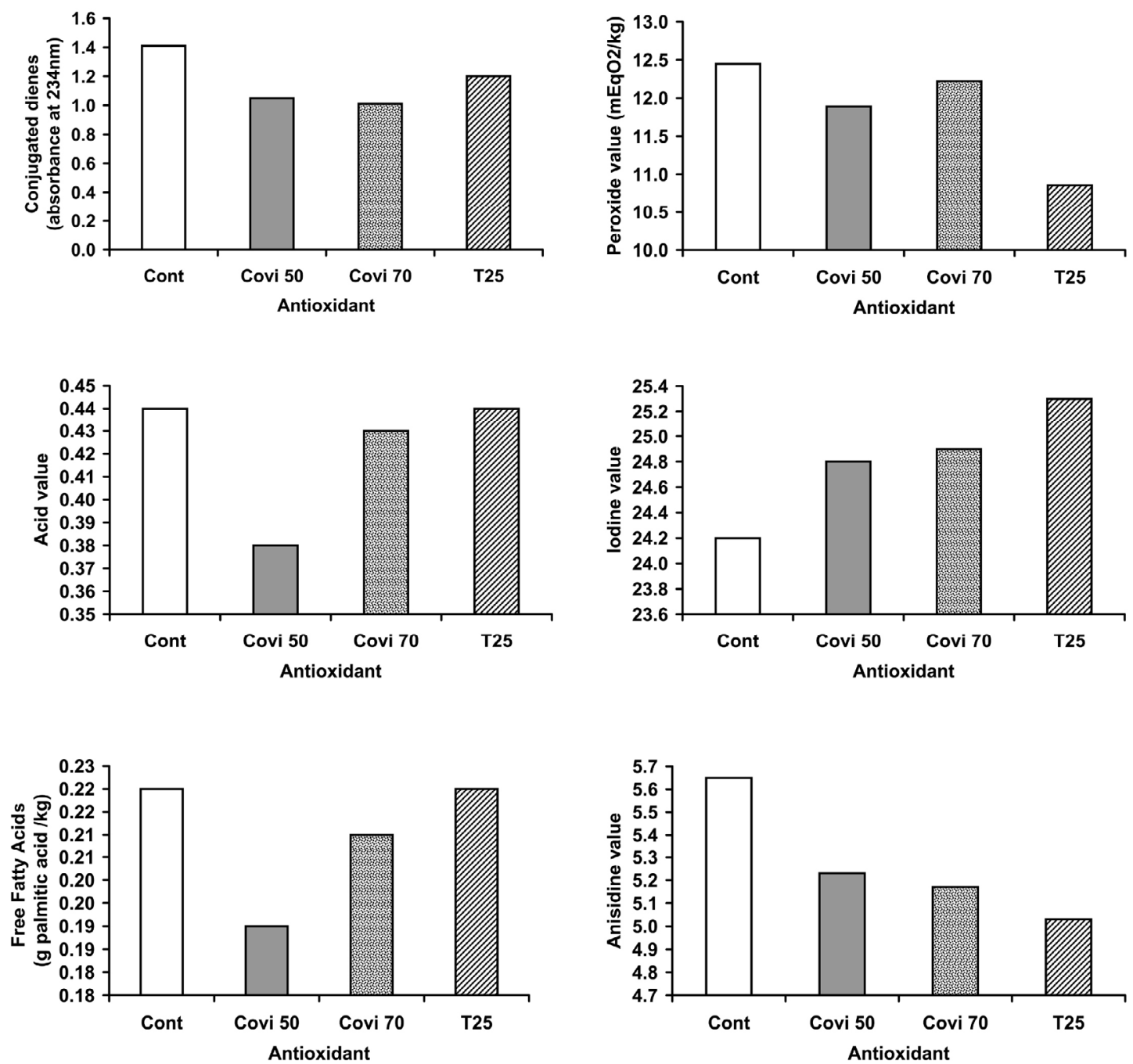

Fig. 1: The effect of added levels of natural and synthetic antioxidants on the stability of palm olein as measured by some chemical parameters

tocopherol concentrate Covi 50 significantly $(\mathrm{P}<0.05)$ reduced both the AV and FFA values as compared to the control and the other antioxidant. Palm olein oil is the liquid fraction produced by fractionation of crude palm oil. Thus, strong enzyme activity from the pressed fruit pulp of the oil palm may lead to hydrolytic rancidity which is usually not responsive to most antioxidants (Calvo, 1993). It was also reported by Eastman (1995) that neither the TBHQ nor the BHT have any significant effect on palm oil olein at levels less than 25ppm, but at levels greater than 25ppm, TBHQ is far more effective than BHT.

Results of the peroxide values (PV) of the stored palm olein indicated that the most effective antioxidant which significantly $(\mathrm{P}<$ 0.05 ) reduced the rise in PV under the experimental conditions was T $25(10.86 \mathrm{mEq}$ $\left.\mathrm{O}_{2} \mathrm{~kg}\right)$ followed by Covi $50\left(11.89 \mathrm{mEqO} \mathrm{F}_{2}\right.$ $/ \mathrm{kg}$ ) as compared to both Covi 70 and control
(Fig. 1). These results are in accordance with Anon (1991) and Allam \& Mohammed (2002). Changes in the iodine value (IV) of the stored palm olein due to loss of unsaturation during oxidation are shown in Fig. (1). The synthetic antioxidant T 25 significantly $(\mathrm{P}<0.05)$ reduced oxidation as compared to control. As a matter of fact, both tocopherols were significantly more effective in reducing the onset of oxidation in the stored palm olein than the control but less effective than T 25. It was confirmed by Buck \& Edwards (1997) that TBHQ is still the superior single antioxidant for most fats and oils especially vegetatble oils. It was also reported that BHA and TBHQ demonstrate their synergistic effect when used in combination. Sims \& Fioriti (1980) mentioned that the stabilizing properties of TBHQ can be further enhanced by using a chelating agent such as citric acid. 
Both synthetic and natural antioxidants used in the present study exhibited a significant reduction in the p-anisidine (PA) values as compared to control (Fig. 1). No significant differences were observed between the effect of the synthetic antioxidant T 25 and the natural Covi 70 in this respect emphasizing the pronounced effect of the later. The PA value measures the compounds resulting from the breakdown of the peroxides such as betaaldehydes.

The total oxidation value (TOTOX) which is used to determine the effectiveness of oils kept at room temperature giving the total picture of oxidation deterioration is given in Table (1). As it can be seen, T25 followed by Covi 50 were the most effective antioxidants for palm olein. As a matter of fact, the synergistic effect of TBHQ and BHT in the synthetic antioxidant T25 was apparent in reducing the total TOTOX value. It can also be seen from Table (1) the antioxidant index (AI) for the different antioxidants, all antioxidants used in the present study had values higher than unity throughout the storage period indicating their antioxidative power. Both natural tocopherols exerted AI values comparable to a great extent to T25 which slightly exceeded them emphasizing the comparable effect of the tocopherol mixtures and the synthetic antioxidant T25 used in the present study in stabilizing the onset of oxidation in the stored palm olein.

Results in Table (2) indicated a distinct significant $(\mathrm{P}<0.05)$ decrease in the moisture content of the stored biscuits as time proceeded. The moisture content at zero time was $8.93 \%$ dropped to $6.91 \%$ at the end of the storage period. As a matter of fact, the antio- xidant addition of Covi 50 to the palm olein oil significantly $(\mathrm{P}<0.05)$ reduced the loss in moisture $(8.24 \%)$ of the stored biscuits as compared to the other antioxidants and control. Generally, the loss of moisture in the stored biscuits under tropical conditions (high temperature and humidity) may be explained due to the equilibrium relative humidity (ERH) of bakery products which make them liable to loss of moisture rather than gaining it (Manley, 1996). It is also possible that solutes may play a role in controlling the movement of water in food products (Almasi, 1979), which may explain the effect of Covi 50 in controlling water loss as compared to the other antioxidants. It was also observed from Table (2) the presence of a significant $(\mathrm{P}<0.05)$ drop in the $\mathrm{pH}$ of the stored biscuits as a function of time. The initial $\mathrm{pH}$ of the biscuits was 7.45 , dropped to 7.30 at the end of the storage period probably due to hydrolytic activity catalyzed by temperature and lipolytic enzymes (Stuckey, 1980). Both added natural and synthetic antioxidants were significantly equally effective $(\mathrm{P}<0.05)$ in preventing hydrolytic rancidity in the stored biscuits as compared to control.

The thiobarbituric acid (TBA) number of the stored biscuits increased significantly $(\mathrm{P}<$ 0.05 ) with the elapse of time. It was obvio-us that the addition of Covi 50 was signific-antly $(\mathrm{P}<0.05)$ effective in controlling the onset of rancidity as compared to the control and the other tested antioxidants (Table 2). Manley (1996) reported that not all the changes which occur during storage are due to the moisture pick-up. Conditions of temperature and humidity are very important in biscuits stores. High or fluctuating temperature may cause fat

Table 1: The total oxidation value and antioxidant index of palm olein stored at tropical conditions for 4 months

\begin{tabular}{lcccc}
\hline Treatment & $\begin{array}{c}\text { Mean }^{\mathbf{1}} \\
\text { PA }\end{array}$ & $\begin{array}{c}\text { Mean }^{2} \\
\text { PV }\end{array}$ & TOTOX $^{3}$ & AI $^{\mathbf{4}}$ \\
\hline Control & 5.65 & 12.45 & 30.55 & --- \\
Covi 50 & 5.23 & 11.89 & 29.01 & 1.04 \\
Covi 70 & 5.17 & 12.22 & 29.61 & 1.01 \\
T25 & 5.03 & 10.86 & 26.75 & 1.15 \\
\hline
\end{tabular}

${ }^{1}$ Mean p-anisidine value of antioxidant treatment.

${ }^{2}$ Mean peroxide value of antioxidant treatment.

${ }^{3}$ TOTOX $=$ PA +2 (PV).

${ }^{4} \mathrm{AI}=\mathrm{PV}$ control $\div \mathrm{PV}$ treatment. 
Table 2: Effect of different added levels of natural and synthetic antioxidants on the quality of biscuits stored at tropical conditions for $\mathbf{4}$ months

\begin{tabular}{|c|c|c|c|c|c|c|}
\hline \multirow{2}{*}{$\begin{array}{l}\text { Tested pa- } \\
\text { rameters }\end{array}$} & \multirow{2}{*}{$\begin{array}{l}\text { Storage } \\
\text { time } \\
\text { (months) }\end{array}$} & \multicolumn{4}{|c|}{ Treatments } & \multirow{2}{*}{$\begin{array}{c}\text { Mean (x) } \\
\text { time }\end{array}$} \\
\hline & & Cont. & Covi 50 & Covi 70 & T25 & \\
\hline \multirow{6}{*}{ Moisture } & 0 & 9.07 & 9.63 & 8.36 & 8.68 & $8.93^{\mathrm{a}}$ \\
\hline & 1 & 8.56 & 9.46 & 7.60 & 8.13 & $8.43^{\mathrm{b}}$ \\
\hline & 2 & 8.10 & 8.49 & 7.35 & 7.17 & $7.77^{\mathrm{c}}$ \\
\hline & 3 & 7.72 & 6.86 & 7.33 & 7.15 & $7.26^{\mathrm{d}}$ \\
\hline & 4 & 7.17 & 6.79 & 7.03 & 6.66 & $6.91^{\mathrm{e}}$ \\
\hline & $\overline{\mathrm{x}}$ treatment & $8.12^{\mathrm{a}}$ & $8.24^{\mathrm{b}}$ & $7.53^{\mathrm{c}}$ & $7.55^{\mathrm{c}}$ & \\
\hline \multirow{6}{*}{$\mathrm{pH}$} & 0 & 7.48 & 7.45 & 7.44 & 7.46 & $7.45^{\mathrm{a}}$ \\
\hline & 1 & 7.40 & 7.43 & 7.40 & 7.44 & $7.41^{\mathrm{b}}$ \\
\hline & 2 & 7.38 & 7.41 & 7.39 & 7.40 & $7.39^{\mathrm{b}}$ \\
\hline & 3 & 7.33 & 7.38 & 7.36 & 7.34 & $7.35^{\mathrm{c}}$ \\
\hline & 4 & 7.25 & 7.35 & 7.34 & 7.30 & $7.30^{\mathrm{d}}$ \\
\hline & $\overline{\mathrm{x}}$ treatment & $7.36^{\mathrm{a}}$ & $7.40^{\mathrm{b}}$ & $7.38^{\mathrm{b}}$ & $7.38^{\mathrm{b}}$ & \\
\hline \multirow{6}{*}{ TBA* } & 0 & 0.20 & 0.15 & 0.19 & 0.14 & $0.17^{\mathrm{a}}$ \\
\hline & 1 & 0.23 & 0.21 & 0.29 & 0.22 & $0.23^{\mathrm{b}}$ \\
\hline & 2 & 0.29 & 0.22 & 0.26 & 0.19 & $0.24^{\mathrm{b}}$ \\
\hline & 3 & 0.30 & 0.22 & 0.29 & 0.28 & $0.27^{\mathrm{b}}$ \\
\hline & 4 & 0.34 & 0.26 & 0.30 & 0.42 & $0.33^{\mathrm{c}}$ \\
\hline & $\overline{\mathrm{x}}$ treatment & $0.27^{\mathrm{a}}$ & $0.21^{\mathrm{b}}$ & $0.26^{\mathrm{a}}$ & $0.25^{\mathrm{ab}}$ & \\
\hline
\end{tabular}

Cont : Control 100\% palm olein

Covi 50 : Palm olein + Low tocopherol concentrate

Covi 70 : Palm olein + High teocopherol concentrate

T 25 : Palm olein + Synthetic antioxidant

Means having different letters are significantly different at $(\mathrm{P}<0.05)$

* mg malonaldehyde/kg sample

migration and rancidity problems. Results generally confirm the effectiveness of the low tocopherol concentrate Covi 50 in controlling the quality of the biscuits stored under the aforementioned experimental conditions as compared to the control.

Sensory evaluation: The panelists' scores for the different sensory attributes of the biscuits containing antioxidants and control stored at a temperature range of 37 to $45^{\circ} \mathrm{C}$ for 4 months are given in Table (3). Results indicated no significant differences concerning the scores given by the panelists for the colour as a function of time and treatment. On the other hand, pronounced differences were observed in the taste and texture attributes where higher scores were more given by the panelists for the antioxidant treated samples, where no significant differences were observed between them but were significantly different $(\mathrm{P}<0.05)$ from the con- trol. These results were more confirmed from the overall acceptance of the panelists who showed a tendency towards the antioxidant treated biscuits. It is confirmed by Buck \& Edwards (1997) who stated that antioxidants that will survive elevated temperatures such as tocopherols are required for baking and frying purposes. Tocopherols due to their high molecular weight resist high temperature processing. It was also reported by Eastman (1995) that palm oil which contains short chain fatty acids and are quite saturated respond well to the action of TBHQ that works well in such fats.

It may be observed from the aforementioned oxidation measurements and quality tests that the activity of the individual antioxidants used in the present study varied with the same type of oil. This condition was explained by Calvo (1993) as depending on temperature. It was also reported by Lauridsen 
Table 3: Effect of different added levels of natural and synthetic antioxidants on the sensory attributes of biscuits stored at tropical conditions for $\mathbf{4}$ months

\begin{tabular}{|c|c|c|c|c|c|c|}
\hline \multirow{2}{*}{$\begin{array}{c}\text { Sensory at- } \\
\text { tribute }\end{array}$} & \multirow{2}{*}{$\begin{array}{c}\text { Storage } \\
\text { time } \\
\text { (months) }\end{array}$} & \multicolumn{4}{|c|}{ Treatments } & \multirow{2}{*}{$\begin{array}{c}\text { Mean (x) } \\
\text { time }\end{array}$} \\
\hline & & Cont. & Covi 50 & Covi 70 & T25 & \\
\hline \multirow{6}{*}{ Colour } & 0 & 4.1 & 3.9 & 4.5 & 4.6 & $4.27^{\mathrm{a}}$ \\
\hline & 1 & 4.5 & 4.4 & 4.5 & 4.2 & $4.40^{\mathrm{a}}$ \\
\hline & 2 & 3.7 & 3.3 & 4.9 & 4.5 & $4.10^{\mathrm{a}}$ \\
\hline & 3 & 4.0 & 4.3 & 3.8 & 4.0 & $4.02^{\mathrm{a}}$ \\
\hline & 4 & 4.0 & 4.2 & 4.0 & 3.8 & $4.00^{\mathrm{a}}$ \\
\hline & $\overline{\mathrm{x}}$ treatment & $4.06^{\mathrm{a}}$ & $4.02^{\mathrm{a}}$ & $4.34^{\mathrm{a}}$ & $4.22^{\mathrm{a}}$ & \\
\hline \multirow{6}{*}{ Odour } & 0 & 4.4 & 4.5 & 4.6 & 4.5 & $4.50^{\mathrm{a}}$ \\
\hline & 1 & 4.6 & 4.6 & 4.6 & 4.5 & $4.57^{\mathrm{a}}$ \\
\hline & 2 & 4.2 & 4.4 & 4.4 & 4.6 & $4.40^{\mathrm{a}}$ \\
\hline & 3 & 3.5 & 3.9 & 3.4 & 4.5 & $4.02^{\mathrm{b}}$ \\
\hline & 4 & 3.5 & 4.5 & 3.6 & 4.2 & $3.82^{\mathrm{b}}$ \\
\hline & $\overline{\mathrm{x}}$ treatment & $4.04^{\mathrm{a}}$ & $4.38^{\mathrm{ab}}$ & $4.18^{\mathrm{ab}}$ & $4.46^{\mathrm{c}}$ & \\
\hline \multirow{6}{*}{ Taste } & 0 & 4.2 & 4.3 & 4.9 & 4.1 & $4.37^{\mathrm{a}}$ \\
\hline & 1 & 4.1 & 4.3 & 4.3 & 4.1 & $4.20^{\mathrm{ab}}$ \\
\hline & 2 & 3.8 & 4.4 & 4.4 & 4.1 & $4.18^{\mathrm{ab}}$ \\
\hline & 3 & 3.7 & 4.1 & 3.4 & 4.5 & $3.92^{\mathrm{b}}$ \\
\hline & 4 & 3.9 & 4.2 & 3.6 & 3.7 & $3.85^{\mathrm{b}}$ \\
\hline & $\overline{\mathrm{x}}$ treatment & $3.94^{\mathrm{a}}$ & $4.27^{b}$ & $4.12^{b}$ & $4.10^{b}$ & \\
\hline \multirow{6}{*}{ Texture } & 0 & 3.7 & 3.9 & 4.3 & 4.0 & $3.97^{\mathrm{a}}$ \\
\hline & 1 & 3.9 & 4.4 & 4.5 & 3.8 & $4.15^{\mathrm{a}}$ \\
\hline & 2 & 4.0 & 4.3 & 4.6 & 4.0 & $4.23^{\mathrm{a}}$ \\
\hline & 3 & 3.7 & 4.3 & 4.0 & 4.0 & $4.00^{\mathrm{a}}$ \\
\hline & 4 & 3.8 & 4.1 & 4.4 & 3.6 & $3.95^{\mathrm{a}}$ \\
\hline & $\overline{\mathrm{x}}$ treatment & $3.82^{\mathrm{a}}$ & $4.20^{\mathrm{b}}$ & $4.36^{\mathrm{b}}$ & $3.82^{\mathrm{a}}$ & \\
\hline \multirow{6}{*}{$\begin{array}{l}\text { Overall accep- } \\
\text { tance }\end{array}$} & 0 & 4.0 & 4.2 & 4.4 & 4.1 & $4.17^{\mathrm{a}}$ \\
\hline & 1 & 4.1 & 4.3 & 4.4 & 4.3 & $4.27^{\mathrm{a}}$ \\
\hline & 2 & 3.8 & 4.2 & 4.3 & 4.0 & $4.07^{\mathrm{ab}}$ \\
\hline & 3 & 3.8 & 4.2 & 3.8 & 3.8 & $3.90^{\mathrm{ab}}$ \\
\hline & 4 & 3.5 & 3.9 & 3.4 & 4.3 & $3.77^{\mathrm{b}}$ \\
\hline & $\overline{\mathrm{x}}$ treatment & $4.80^{\mathrm{a}}$ & $4.16^{\mathrm{b}}$ & $4.06^{\mathrm{b}}$ & $4.10^{\mathrm{b}}$ & \\
\hline
\end{tabular}

Cont : Control $100 \%$ palm olein.

Covi 50 : Palm olein + Low tocopherol concentrate.

Covi 70 : Palm olein + High teocopherol concentrate.

T 25 : Palm olein + Synthetic antioxidant.

Means having different letters are significantly different at $(\mathrm{P}<0.05)$.

\& Schultz (1993) and Berry (2003) that the performance of antioxidants depends not only on their chemical structure but also on the composition of food-stuff to be protected, the manufacturing conditions of the products, the synergistic effects with other ingredients, the inherent antioxidant (e.g. tocopherols) present in the oil as well as the degree of unsaturation.

\section{REFERENCES}

Allam, S.S.M. \& Mohamed, H.M.A. 2002. Thermal stability of some commercial natural and synthetic antioxidants and their mixtures. J. Food Lipids, 9: 277-294.

Almasi, E. 1979. Dependence of the amount of bound water of foods on temperature. ACTA Aliment. 8 (1): 41-56. 
Anon 1991. Natural antioxidants capitalize on clean label trend. Prepared Foods, 160 (8): 83-85.

AOAC 1984. Official Methods of Analysis, $14^{\text {th }}$ ed. Association of Official Analytical Chemists, Washington, DC.

AOCS 1990. Official Methods and Recommended Practices of the American Oil Chemists' Society $4^{\text {th }}$ (ed) American Oil Chemists' Society, Champaign, IL, USA.

Barrera, A.D., Ruiz, M.V., Velasco, J. Márquez, R.G. \& Dobarganes, C. 2002. Loss of tocopherols and formation of degradation compounds at frying temperatures in oils differing in degree of usaturation and natural antioxidant content. J. Sci. Fd. Agric. 82: 1696-1702.

Berry, D. 2003. Fat's chance. Food Product Design: Applications, June, p. 1-7.

Bishov, I. \& Henick, A. 1972. Antioxidant effect of protein hydrolysates in a freeze-dried model system. J. Food Sci. 37(6): 573875.

Buck, D.F. \& Edwards, M.K. 1997. Antioxidants to prolong shelf-life. Food Technology International, p. 29-33.

Calvo, A. 1993. Effective of commercial antioxidants. Oils and Fats International 9(2): 1416.

Conforti, F.D., Chalres, S.A. \& Duncan, S.E. 1997. Evaluation of a carbohydratebased fat replacer in a fat-reduced baking powder biscuit. J. Food Quality 20: 247256.

Doughrety, M.E. 1988. Tocohperols as food antioxidants. Cereal Foods World. 33: 222232.

Eastman 1995. Tenox TBHQ Antioxidant Versus BHT in Fat and Oils. Publication No. Z15. Eastman Chemical Company, Kingsport, TN37668-5280, USA.

Eastman 1996. Tenox Food Grade Antioxidants. Eastman Publication No. ZG-262C. Eastman Chemical Company, Kingsport, TN 37668-5230, USA.

Egan, H., Kirk, S., \& Sawyer, R. 1981. Oils and Fats, In : Pearson's Chemical Analysis of Food, $8^{\text {th }}$ ed. London Group Ltd. NY, p. 522.

Frankel, E.N. 1996. Antioxidants in lipid foods and their impact on food quality. Food Chem. 57: 51-55.

Gordon, M.H. \& Kourimska, L. 1995. The effects of antioxidants on changes in oils during heating and deep frying. J. Sci. Fd Agric., 68 (3): 347-353.
Haung, S.W., Frankel, E.N. \& German, J.B. 1995. Effects of individual tocopherols and tocopherol mixtures on the oxidative stability of corn oil triglycerides. J. Agric. Food. Chem. 43: 2345-2350.

International Union of Pure Applied Chemistry (IUPAC) 1978. Standard Methods for the Analysis of Oils and Fats and Derivatives (IUPAC), $7^{\text {th }}$ edition, Blackwell Scientific Publ. Ltd., Polo, Alto, C.A.

International Union of Pure and Applied Chemistry (IUPAC) 1979. Standard Methods for the Analysis of oils, fats and derivatives. Methods 2.504-Paquot, C. (ed.), $6^{\text {th }}$ edition, Pergomon Press, Oxford, England, pp. 143-144.

Lauridsen, J.B. \& Schutz, A.M. 1993. Antioxidants: Improving the shelf-life of food products. Food Marketing \& Technology, October, Key, No. 36977, p. 6-10.

Loliger, J. 1991. Natural antioxidants. Lipid Technology, 4: 58-61.

Loliger, J. \& Wille, H.J. 1993. Natural antioxidants. Oils and Fats International, 9: 1822.

Longani, M.K. \& Davis, R.E. 1980. Lipid oxidation : Biological effects and antioxidants. A Review. Lipids 15: 485-495.

Manley, D. 1996. Technology of Biscuits, Crackers and Cookies. Woodhead Publishing Limited, Abington Hall, Abington, Cambridge, England.

Moskwitz, H.R. 1985. New Directions for Product Testing and Sensory Analysis of Foods. Food Nutrition Press, Trumbull, Connecticut.

Poller, F. 1992. Natural antioxidants: A concept of designer foods for cancer prevention. Journal of the National Cancer Institute, 84: 1690-1691.

Pszola, D.E. 2001. Antioxidants: From preserving food quality to quality of life. Food Technol. 55: 51-59.

Romero, F.J., Morell, F.B ., Romero, M.J., Jareno, E.J., Romero, B., Marin, N. \& Romá, J. 1998. Lipid peroxidation products and antioxidants in human disease. Environ. Health Perspect 106 (Suppl 5): 12291234.

SAS 1985. Statistical Analysis System, $5^{\text {th }}$ ed, Statistical Analysis System Institute, Cary, NC.

Shahidi, F. 1996. Natural Antioxidants : Chemistry, Health Effects and Applications. AOCS Press, Champaign, Illinois.

Sims, R.J. \& Fioriti, J.A. 1980. Antioxidants as Stabilizers for Fats, Oils and Lipid Con- 
taining Foods In : Furta, T.E. (ed), CRC Handbook of Food Additives. Vol. 1. CRC Press, Boca Raton, FL, pp. 13-56.

Stuckey, B.N. 1980. Antioxidants as Food Stabilizers. In : Furta T.E. (ed.) CRC Handbook of Food Additives CRC Press Boca Raton FL, pp. 185-223.

Tarladgis, B.G., Watts, B.M., Younathan, M.T. \& Dugan, L. 1960. A distillation method for the quantitative determination of malonaldehyde in rancid food. J. Am. Oil Chem. Soc. 37: 44-48.
Topliss, J.G., Clark, A.M., Ernest, E., Huffozd, C.D., Johnston, G.A.R., Rimoldi, J.M. \& Weimann, B.J. 2002. Natural \& synthetic substances related to human health. Pure Appl. Chem., 74: 1957-1985.

Tomasch, K.H. \& Elmadfa, W.J. 2001. Antioxidants power of plant oils in humans : The influence of $\alpha$ - and $\gamma$ - tocopherol. Annals of Nutrition \& Metabolism 45: 110-115.

Wu, K. 1994. Autoxidation and stabilization of polyunsaturated oils. Dissertation Abstracts International B 54 (8) 3922, 267pp.

\section{تأثير التوكوفيرولات المضافة على ثبات زيت أوليين النخيل والبسكويت المحتوي عليه تحت الظروف الاستوائية

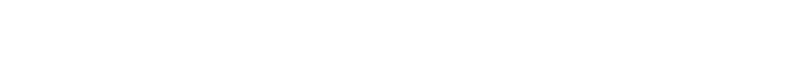

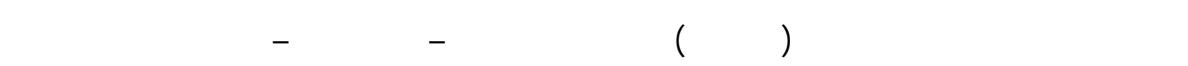

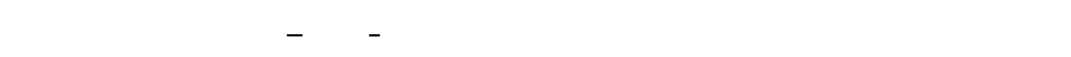

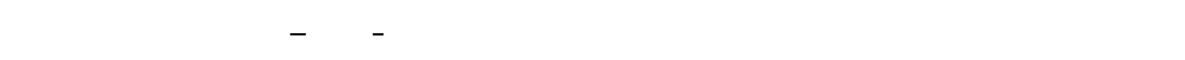

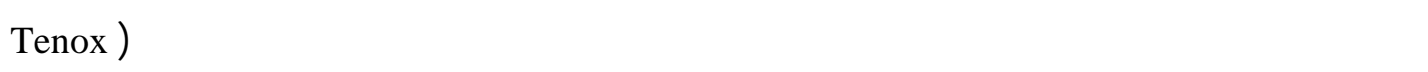

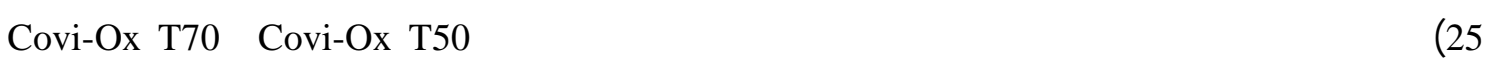

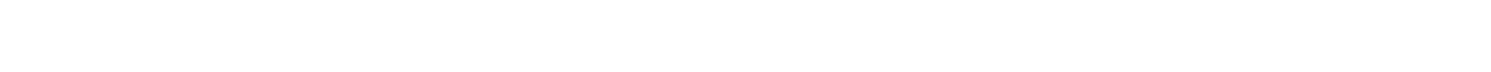

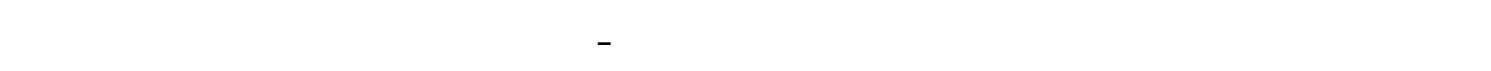

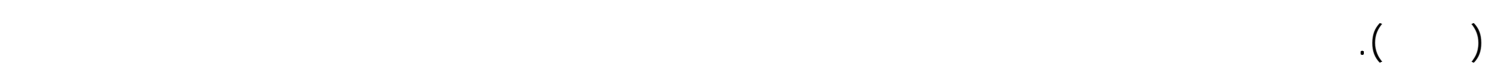

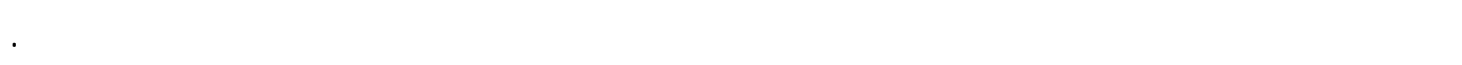

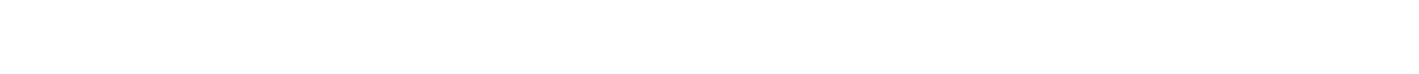

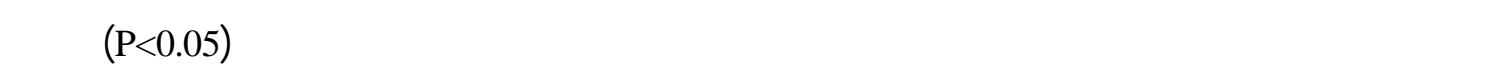

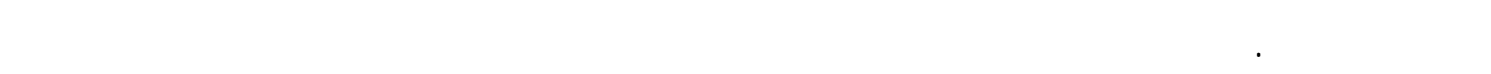

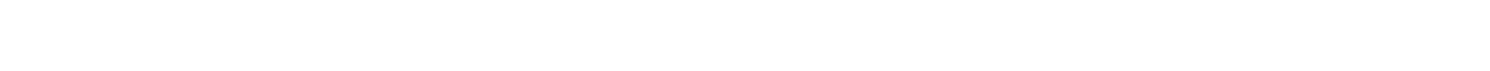
في تشبيطظروف التزنخ على الزيت المخزن.

وقد أظهرت نتائج لختبارات الجودة للبسكويت المخزن أن التوكوفيرولات منخفضة الترونة التركيز (Covi 50)

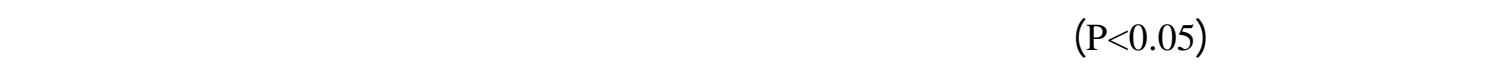

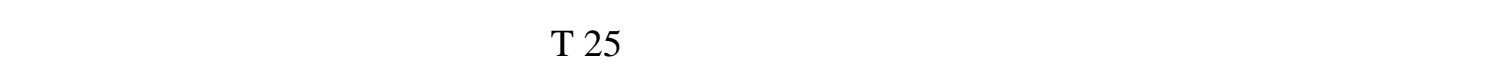

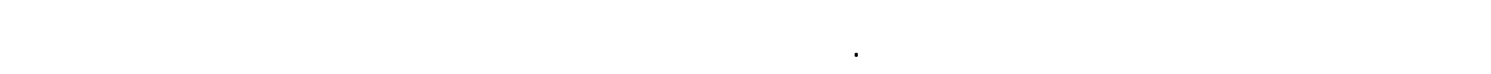

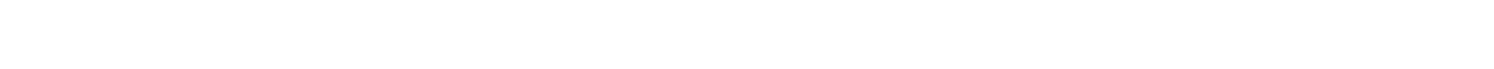

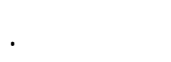


